\title{
Delayed Gastric Emptying in Patients with Prader Willi Syndrome
}

\author{
T. Arenz ${ }^{1}$, A. Schwarzer ${ }^{2}$, Th. Pfluger ${ }^{3}$, S. Koletzko ${ }^{2}$ and H. Schmidt ${ }^{2}$ \\ ${ }^{1}$ Inselspital, Children's Hospital of the University Berne, ${ }^{2}$ Dr. von Haunersches Kinderspital of the \\ Ludwig-Maximilians-University of Munich, ${ }^{3}$ Department of Nuclear Medicine of the Ludwig-Maximilians- \\ University of Munich, Germany
}

\section{ABSTRACT}

Background: A 15 year old girl with PraderWilli Syndrome (PWS) died of gastric rupture. Systematic literature research revealed seven case reports of PWS patients with acute gastric dilatation, two had a lethal course. The objective of this study was to determine if delayed gastric emptying in PWS patients might contribute to gastric dilatation.

Methods: Gastric emptying was measured in eight patients with PWS by nucleotid scintigraphy after a standardized test meal. Results: Median age was 17.8 years (range 10.119.5). Median BMI of the male patients was 29.5 (range 18.4-34.8), of the female patients 28 (range 20.0-44.8). Half time of gastric emptying was delayed in five of the eight patients (median 78.5 minutes, range 59-134).

Conclusion: Scintigraphic measurement of gastric emptying in eight PWS patients revealed delay in comparison to normal values. This might be a risk factor for gastric dilatation and rupture in patients with PWS.

\section{KEY WORDS}

Prader-Willi Syndrome, gastric emptying, gastric rupture

\section{ABBREVIATIONS}

$\begin{array}{ll}\text { kcal } & \text { kilocalories } \\ \text { NSAID’s } & \text { non steroidal antirheumatic drugs } \\ \text { PWS } & \text { Prader Willi Syndrome }\end{array}$

Corresponding author:

Prof. Dr. Heinrich Schmidt

Heinrich.Schmidt@med.uni-muenchen.de

\section{INTRODUCTION AND} PATIENT REPORT

PWS is a rare genetic disorder characterized by muscular hypotonia, feeding difficulties during infancy and hyperphagia after the age of two to four years leading to obesity, short stature, as well as mental and motoric retardation $^{1,2}$. As a severe gastrointestinal complication gastric rupture was reported by Wharton and colleagues ${ }^{3}$. We observed a similar dramatic course of the disease in a 15 year old girl with PWS. She had been under hypocaloric diet and growth hormone treatment for ten years. She presented in a children's hospital with abdominal pain. Acute gastroenteritis was suspected and symptoms were treated. After three days, the patient could be discharged without any complaints on a dietary food. Two days later abdominal pain recurred. One day later the patient was readmitted with an acute abdomen as well as symptoms of cardiovascular shock. Emergency surgery was performed which showed a huge and completely ruptured stomach without any signs of inflammation or ulceration. The girl died after two hours because of multiorgan failure. Histology showed no signs of inflammation, no $H$. pylori infection and no peptic ulcer, respectively. It was suspected that an ischaemic lesion of the stomach had led to the perforation. There was no previous episode of binge eating. We reviewed the literature and found a case series including six female and one male PWS patients suffering from gastric dilatation, two with lethal outcome ${ }^{3}$. The objective of this study was to measure gastric emptying in patients with PWS as a possible etiologic factor for acute gastric dilatation and necrosis. 


\section{PATIENTS AND METHODS}

\section{Patients}

In this clinical observation study, eight patients with genetically confirmed PWS, all on dietary treatment and regularly followed up in our outpatient clinics, were included.

Written informed consent of the patients and/or their parents was obtained. Patients did not take any medications and were not on growth hormone treatment (Table 1).

TABLE 1

Characteristics of eight patients with PWS and time of diagnosis

\begin{tabular}{lccl}
\hline Patient & Gender & $\begin{array}{c}\text { Age at diagnosis } \\
\text { of PWS [years] }\end{array}$ & $\begin{array}{l}\text { Genetic } \\
\text { diagnosis }\end{array}$ \\
\hline 1 & F & 0.2 & del \\
2 & F & 2.8 & del \\
3 & M & 13.0 & del \\
4 & F & 4.9 & i.m. \\
5 & M & 4.3 & del \\
6 & M & 5.3 & mupd \\
7 & M & 0.4 & del \\
8 & F & 5.0 & del \\
\hline
\end{tabular}

del $=$ microdeletion chromosome 15

i.m. = imprinting mutation mupd $=$ maternal uniparental disomie

\section{BMI}

For children and adolescents the percentiles for German children were used ${ }^{4}$, for adult PWS patients we used the references from the $\mathrm{WHO}^{5}$.

\section{Dietary treatment}

All patients had a special hypocaloric and fat reduced diet $(10 \mathrm{kcal} / \mathrm{cm}$ body length, $20 \%$ fat, $55 \%$ carbohydrates, $25 \%$ protein $)^{6,7}$. Median age at beginning of the diet was 14.5 years (range 219). Seven of the eight patients were on this diet for at least one year and one patient started the diet six months before gastric emptying measurement, respectively.

\section{Gastric emptying}

After an overnight fast of $12 \mathrm{~h}$, gastric emptying was measured by nucleotid scintigraphy after a liquid standardized test meal of $200 \mathrm{ml}$ Frebini ${ }^{\circledR}$ (Fresenius, $1 \mathrm{kcal} / \mathrm{ml}$ ). For scintigraphic measurement Tc-99m-DTPA (Technicium-99mDiethylene Triamine Pentaacetic Acid) (20 MBq) was used as tracer.

\section{Scintigraphy technique}

A dual headed gamma camera (Picker-Prism 2000XP, Picker International, Cleveland, Ohio, USA) with a low energy collimator and interfaced with a computer was used for data acquisition. For the scintigraphy, the field of view was centred over the stomach where a region of interest was defined. The acquisition of images was started immediately after the ingestion of the test meal while the patients were placed in a supine position. Dynamic scanning was obtained over a time frame of up to 45 minutes. Residual activity in the stomach 30 minutes after ingestion of the test meal was measured and half emptying time (min) (t1/2s) of the stomach was calculated using established methods, as previously described ${ }^{8}$.

For the half emptying time in scintigraphic emptying testing a cut-off of $\mathrm{t} 1 / 2 \mathrm{~s} \geq 60$ min was chosen established by former studies ${ }^{9}$.

\section{RESULTS}

The median age of the eight patients at gastric emptying measurement was 17.8 years (range 10.1-19.5). Patients' characteristics, anthropometric data, and gastric emptying times are shown in Table 1 and Table 2. Three of the eight patients had normal weight, five of them fulfilled the criteria for obesity (adults: BMI $>30 \mathrm{~kg} / \mathrm{m}$, children: BMI $>97^{\text {th }}$ percentile). Five patients showed delayed gastric emptying, and three values at the upper limit of normal, with a median time of 82 minutes (range 59-134). 
TABLE 2

Age, weight, BMI, BMI percentile and scintigraphic half time at time of gastric emptying measurement

\begin{tabular}{|c|c|c|c|c|c|c|}
\hline Patient & $\begin{array}{c}\text { Age at } \\
\text { examination } \\
\text { [years] }\end{array}$ & $\begin{array}{c}\text { Weight } \\
{[\mathrm{kg}]}\end{array}$ & $\begin{array}{c}B M I \\
{\left[\mathrm{~kg} / \mathrm{m}^{2}\right]}\end{array}$ & $\begin{array}{c}\text { BMI } \\
\text { percentile }\end{array}$ & Obesity & $\begin{array}{c}\text { Scintigraphic } \\
\text { half time } \\
\text { [minutes] }\end{array}$ \\
\hline 1 & 15.3 & 43.00 & 22.9 & 83 & no & 90.0 \\
\hline 2 & 17.2 & 48.00 & 19.9 & 33 & no & 59.0 \\
\hline 3 & 19.4 & 81.2 & 30.2 & 99 & yes & 59.0 \\
\hline 4 & 17.6 & 74.6 & 33.0 & $>100$ & yes & 60.0 \\
\hline 5 & 17.9 & 68.9 & 28.71 & 98 & yes & 76.0 \\
\hline 6 & 19.1 & 89.0 & 34.8 & $>100$ & yes & 81.0 \\
\hline 7 & 10.2 & 37.2 & 18.4 & 72 & no & 99.0 \\
\hline 8 & 19.5 & 93.9 & 44.8 & $>100$ & yes & 134.0 \\
\hline
\end{tabular}

\section{DISCUSSION}

\section{Gastrointestinal manifestations in patients with PWS}

This prospective study reports delayed and borderline gastric emptying in eight patients with PWS. Our results confirm the findings of Choe et al, who performed scinitigraphic gastric emptying studies with a standard meal of solid food in eleven children with $\mathrm{PWS}^{10}$. Another recent study found gastric emptying times in PWS similar to lean healthy controls but significantly increased compared to obese controls ${ }^{11}$. Sudden death after gastric rupture in patients with PWS has already been described by Wharton et al. They reported severe gastric dilatation in six female and one male patient. Two of the patients (23 and 37 years) died after rupture. In two girls (six and seven years) gastric dilatation resolved spontaneously, while in the remaining patients $(21,27$, and 36 years) subtotal gastrectomy had to be performed. The authors speculated that the risk for acute gastric rupture may increase with age after episodes of massive dilatation of the stomach. However, our patient was only 15 years of age with normal weight. Demographic and cause of death data from voluntary familial reporting on PWS patients reported another four male patients $(17,22,24$ and 49 years) with unexpected mortality due to gastric rupture and necrosis and an additional four patients with suspected gastric rupture as cause of death ${ }^{2}$. Causes of death were reported in 27 PWS patients $^{12}$. In children younger than five years of age, they included hypoventilation, aspiration and acute respiratory failure due to infection; two children died after onset of gastrointestinal symptoms and high fever. In the age group older than nine years of age, the causes of death were mainly related to obesity but included two adult males with acute abdominal pain, one of them with severe gastric dilatation ${ }^{12}$. In summary, at least 4 of 27 patients with PWS had suffered from severe gastrointestinal symptoms before their sudden and unexpected death. As the blood supply of the stomach is very rich, including multiple collaterals from extensive intramural anastomoses ${ }^{3}$, ischaemic events normally are very rare. Gastrectomy and biopsy preparations reported by Wharton et al. showed diffuse mucosal infarction with multifocal transmural necrosis as well as vascular dilatation and small thrombi within, in the infarcted areas.

\section{Etiology of gastric dilatation}

Hyperphagia could be one possible explanation for gastric dilatation in PWS patients. However, the published case reports ${ }^{3}$ and the history of our patient revealed no excessive food intake before the acute event. None of the cases in the literature was reported to take ulcerogenic drugs like NSAIDs or corticosteroids. However, four of six patients including our case were reported to have symptoms of acute infectious gastroenteritis before gastric rupture ${ }^{3}$. In PWS a disturbance of hypothalamic regulation (1) seems to be causal for a reduced parasympathic activity, leading to impaired temperature regulation and production of saliva. Furthermore patients with 
PWS usually can not vomit ${ }^{1,10}$.

Therefore we hypothesized that disturbed vagal activity could influence gastric emptying in PWS patients similar to patients with gastroparesis. This could be an explanation for gastric dilatation and in combination with the disturbance of sensibility for pain and extension of the stomach also an explanation for acute gastric rupture. It is not clear whether these patients have an increased feeling of hunger or decreased or even absence of a feeling of satiety ${ }^{11}$. In all cases described in the literature, gastric rupture was a sudden event without any previous alarming signs or symptoms ${ }^{3}$.

TABLE 3

Documented cases of death in PWS patients due to suspected gastric perforation/-rupture - literature review

\begin{tabular}{|c|c|c|c|c|c|c|}
\hline Age & Gender & BMI & Cause of death & $\begin{array}{c}\text { Presenting } \\
\text { Symptoms }\end{array}$ & $\begin{array}{l}\text { Autopsy/ } \\
\text { histopathology }\end{array}$ & References \\
\hline \begin{tabular}{|l|}
23 \\
year
\end{tabular} & female & $\begin{array}{l}\text { no data } \\
\text { available }\end{array}$ & $\begin{array}{l}\text { gastric perforation } \\
\text { and necrosis }\end{array}$ & $\begin{array}{l}\text { diffuse abdominal } \\
\text { pain, vomiting }\end{array}$ & $\begin{array}{l}\text { distended and necrotic } \\
\text { stomach, multiple } \\
\text { subdiaphragmatic abscesses }\end{array}$ & $\begin{array}{l}\text { Wharton et al., Am J } \\
\text { Med Gen } \\
\text { 1997(73):437441 }\end{array}$ \\
\hline \begin{tabular}{|l|}
17 \\
year
\end{tabular} & male & $22 \mathrm{~kg} / \mathrm{m}^{2}$ & $\begin{array}{l}\text { gastric perforation } \\
\text { and necrosis }\end{array}$ & $\begin{array}{l}\text { abdominal pain } \\
\text { and vomiting }\end{array}$ & $\begin{array}{l}\text { microscopic foci of mucosal } \\
\text { ulceration extending to full } \\
\text { necrosis and perforation }\end{array}$ & $\begin{array}{l}\text { Stevenson et al., } \\
\text { JPGN 2007(45):272- } \\
274\end{array}$ \\
\hline \begin{tabular}{|l|}
24 \\
year
\end{tabular} & male & $27 \mathrm{~kg} / \mathrm{m}^{2}$ & $\begin{array}{l}\text { gastric perforation } \\
\text { and necrosis }\end{array}$ & $\begin{array}{l}\text { abdominal pain } \\
\text { and vomiting }\end{array}$ & $\begin{array}{l}\text { transmural gastric necrosis } \\
\text { and focal mucosal ulceration } \\
\text { of the esophageus }\end{array}$ & $\begin{array}{l}\text { Stevenson et al., } \\
\text { JPGN 2007(45):272- } \\
274\end{array}$ \\
\hline \begin{tabular}{|l|}
22 \\
year
\end{tabular} & male & $53,5 \mathrm{~kg}$ & $\begin{array}{l}\text { subsequent gastric } \\
\text { rupturte }\end{array}$ & vomiting & no further data available & $\begin{array}{l}\text { Stevenson et al., } \\
\text { JPGN 2007(45):272- } \\
274\end{array}$ \\
\hline \begin{tabular}{|l|}
49 \\
year
\end{tabular} & male & $\begin{array}{l}50,2 \\
\mathrm{~kg} / \mathrm{m}^{2}\end{array}$ & $\begin{array}{l}\text { "ulcer" with gastric } \\
\text { rupture }\end{array}$ & & no further data available & $\begin{array}{l}\text { Stevenson et al., } \\
\text { JPGN 2007(45):272- } \\
274\end{array}$ \\
\hline \begin{tabular}{|l|}
22 \\
year
\end{tabular} & female & $30 \mathrm{~kg} / \mathrm{m}^{2}$ & $\begin{array}{l}\text { suspected gastric } \\
\text { rupture/and or } \\
\text { necrosis }\end{array}$ & $\begin{array}{l}\text { abdominal pain } \\
\text { and vomiting }\end{array}$ & $\begin{array}{l}\text { markedly distended } \\
\text { abdomen with a gastric tear } \\
\text { and a ,paper-thin“" stomach } \\
\text { wall }\end{array}$ & $\begin{array}{l}\text { Stevenson et al., } \\
\text { JPGN 2007(45):272- } \\
274\end{array}$ \\
\hline \begin{tabular}{|l|}
50 \\
year
\end{tabular} & female & $36 \mathrm{~kg} / \mathrm{m}^{2}$ & $\begin{array}{l}\text { suspected gastric } \\
\text { rupture/and or } \\
\text { necrosis }\end{array}$ & hematemesis & $\begin{array}{l}\text { markedly distended stomach } \\
\text { with erosive gastritis and } \\
\text { evidence of chronic gastritis }\end{array}$ & $\begin{array}{l}\text { Stevenson et al., } \\
\text { JPGN 2007(45):272- } \\
274\end{array}$ \\
\hline \begin{tabular}{|l|}
7 \\
year
\end{tabular} & male & $\begin{array}{l}\text { no data } \\
\text { available }\end{array}$ & $\begin{array}{l}\text { suspected gastric } \\
\text { rupture/and or } \\
\text { necrosis }\end{array}$ & $\begin{array}{l}\text { abdominal pain } \\
\text { and subsequent } \\
\text { hematemesis }\end{array}$ & no further data available & $\begin{array}{l}\text { Stevenson et al., } \\
\text { JPGN 2007(45):272- } \\
274\end{array}$ \\
\hline \begin{tabular}{|l|}
49 \\
year
\end{tabular} & male & $38 \mathrm{~kg} / \mathrm{m}^{2}$ & $\begin{array}{l}\text { suspected gastric } \\
\text { rupture/and or } \\
\text { necrosis }\end{array}$ & hematemesis & no further data available & $\begin{array}{l}\text { Stevenson et al., } \\
\text { JPGN 2007(45):272- } \\
274\end{array}$ \\
\hline
\end{tabular}

\section{Diagnostic and therapeutic consequences}

Patients with PWS are known to have an increased threshold for pain. Furthermore they are usually unable to vomit. Both are contributing risk factors to gastric dilatation and rupture and therefore vomiting and abdominal pain in these patients should be taken especially serious as they are very rare. There should be a prompt diagnostic work-up and careful observation in these patients. As perception of pain is impaired in PWS, analgetic medication should be used carefully, not to mask any symptoms. Furthermore, medications with gastrointestinal 
side effects as NSAIDs and steroids should be avoided. Acceleration of gastric emptying by procinetic agents like domperidon or metroclopramide might be an option in symptomatic patients with delayed gastric emptying. However, further studies are needed to show whether there is any clinical effect and whether episodes of gastric dilatation may be prevented by these interventions.

\section{CONCLUSION}

Scintigraphic measurement of gastric emptying in eight PWS patients revealed delayed gastric emptying in comparison to normal adult values. Delayed gastric emptying might be a risk factor of gastric dilatation and rupture in patients with PWS.

Further studies should evaluate contributing pathophysiological mechanisms and potential prevention of this fatal complication.

\section{ACKNOWLEDGEMENT}

We thank Dr Stephan Arenz for the revision of the manuscript.

\section{REFERENCES:}

1 Goldstone AP: Prader-Willi syndrome: advances in genetics, pathophysiology and treatment. TRENDS in Endocrinology and Metabolism 2004;15:12-20

2 Stevenson DA, Heinemann J, Angulo M, Butler MG, Loker J, Rupe N, Kendell P, Cassidy SB, Scheimann A. Gastric Rupture and Necrosis in Prader-Willi Syndrome. Journal of Pediatric Gastroenterology and Nutrition 2007; 45:272-274.

3 Wharton RH, Wang T, Graeme-Cook F, Briggs S, Cole RE. Acute Idiopathic Gastric Dilatation With
Gastric Necrosis in Individuals With Prader-Willi Syndrome. Am. J. Med. Genet. 1997; 73:437-441.

4 Kromeyer-Hauschild, Wabitsch M, Kunze D, Geller F, Greiß HC, Hesse V, von Hippel A, Jaeger U, Johnson D, Korte W, Menner K, Müller K, Müller JM, Niemann-Pilatus A, Remer T, Schaefer F, Wittchen HU, Zabransky S, Zellner K, Ziegler A, Hebebrand J: Perzentile für den Body-mass-Index für das Kindes-und Jugendalter unter Heranziehung verschiedener deutscher Stichproben. Monatsschr Kinderheilkd 2001;149:807-818

5 WHO Obesity: preventing and managing the global epidemic. WHO Technical Report Series 894, Genf 2000.

6 Schmidt H, Bechtold-Dalla Pozza S, Schwarz HP. Dietary intervention in the first four years prevents abnormal weight gain but negatively affects height development in Prader-Willi Syndrome. Acta paediatr. 2000;90:468-469

7 Schmidt H, Bechtold-Dalla Pozza S, Bonfig W, Schwarz HP, Dokoupil K. Successful early dietary intervention avoids obesity in patients with PraderWilli-Syndrome: a ten year follow up. Accepted by J Ped Endocrinology and metabolism

8 Nysnowitz ML, Benedetto AR: The lag phase of gastric emptying: clinical, mathematical and in vitro studies - J Nucl Med 35: 1023-7, 1994

9 Braden B, Adams S, Duan L, Orth KH, Maul FD, Lembcke B, Hצr G, Caspary WF: The $\left({ }^{13} \mathrm{C}\right)$ acetate breath test accurately reflects gastric emptying of liquids in both liquid and semisolid test meals Gastroenterology 108: 1048-1055, 1995

10 Choe YH, Jin DK, Kim SE, Song SY, Paik KH, Park $\mathrm{HY}$, Oh YI, Kim AH, Kim JS, Kim CW, Chu SH, Kwon EK, Lee KH: Hyperghrelinemia does not accelerate gastric emptying in Prader-Willi-syndrome patients. J Clin Endocrinol Metabol 2005;90:3367

11 Hoybye C, Barkeling B, Naslund E, Thor'n M, Hellstrom PM. Eating Behaviour and Gastric Emptying in Adults with Prader-Willi-Syndrome. Ann Nutr Metabol 2007;51:264-269

12 Schrander-Stumpel CThRM, Curfs LMG, Sastrowijoto P, Cassidy SB, Schrander JJP, Fryns JP. Prader-Willi Syndrome: Causes of Death in an International Series of 27 Cases. American Journal of Medical Genetics 2004; 124A:333-338 